\title{
Evaluation of Serum GH, IGF-1, and IGFBP-3 Levels as Biomarkers in The Diagnosis of Acute Myocardial Infarction
}

\author{
Hüseyin C. HALHALLI ${ }^{1}$, Yücel YÜZBAŞIOĞLU², Kubilay VURAL ${ }^{3}$, Kemal GÜNAYDIN ${ }^{4}$, Figen COŞKUN ${ }^{5}$
}

\footnotetext{
${ }^{1}$ Department of Emergency Medicine, University of Health Sciences, Kocaeli Derince Training and Research Hospital, Kocaeli, Turkey.

${ }^{2}$ Department of Emergency Medicine, Yıldırım Beyazit University, Ankara Atatürk Training and Research Hospital, Ankara, Turkey.

${ }^{3}$ Department of Emergency Medicine, Ordu State Hospital, Ordu, Turkey.

${ }^{4}$ Department of Emergency Medicine, Ankara Training and Research Hospital, Ankara, Turkey.

${ }^{5}$ Department of Emergency Medicine, Faculty of Medicine Hospital, Kırıkkale University, Kırıkkale, Turkey.
}

\section{ABSTRACT}

This study aimed to determine the role of the serum growth hormone and insulin-like growth factor-binding proteins 3 levels measured in the first $24 \mathrm{~h}$ in the diagnosis and pathophysiology of acute myocardial infarction (AMI).

The levels of serum Growth hormone, insulin-like growth factors1, and insulin-like growth factor-binding proteins 3 of the patients diagnosed with AMI in the first $24 \mathrm{~h}$ of onset and that of the control group at the time of admission were compared between January 1 and August 31, 2010.

The average age of the patient group was $59.36 \pm 13: 25$ years, and $79.4 \%$ of the patients were males. The serum growth hormone and insulin-like growth factor-binding proteins 3 levels were significantly higher in the patient group (P < 0.05). However, no differences were found between insulin-like growth factors 1 levels in both the groups (P>0.05). The sensitivity of growth hormone was $84.1 \%$ with a cutoff value of 0.14 ; the sensitivity of insulin-like growth factors 1 was $33.6 \%$ with a cutoff value of 162; and the sensitivity of insulin-like growth factor-binding proteins 3 was $75.7 \%$ with a cutoff value of 2862 .

The present study showed that growth hormone and insulin-like growth factor binding proteins 3 markers play important roles in the pathophysiology of myocardial infarction. Hence, it is thought that they can be used in the diagnosis of AMI. Further studies are needed to validate the conclusion.

Key words: Acute myocardial infarction, GH, IGF-1, IGFBP-3

\section{INTRODUCTION}

Cardiovascular diseases (CVDs) are the most important cause of morbidity and mortality worldwide, and the incidence is increasing rapidly (1). Coronary artery diseases constitute $44 \%$ of the cause of death in Turkey (2). Acute coronary syndromes (ACSs) occur as a result of decreased blood flow to the coronary artery.

Chest pain accounts for about $5 \%$ of the admissions to the emergency department (ED), and the rate of ACS among these cannot be underestimated (3). ACS has been studied in four groups: unstable angina pectoris, ST segment elevated acute myocardial infarction (AMI), non-ST-segment elevated myocardial infarction (MI), and sudden cardiac death (3).

Insulin-like growth factors (IGFS) are involved in cell proliferation, usually depending on the growth hormone (GH) (4). This effect is local and systemic, and starts in the prenatal period (4). Two subtypes are defined as IGF-1 and IGF2, and they circulate in the body fluids together with insulin-like growth factor-binding proteins (IGFBPS) (5). IGF-1 is a polypeptide with endocrine, paracrine, and autocrine functions, which is synthesized in the liver. Approximately $75 \%-80 \%$ of circulating IGF-1 is found to bind with IGFBP-3 (6).

IGF-1 has been found to have positive effects on the development of cardiac structure, contractile function, heart rate, and ejection fraction (7). IGF-1 and IGFBP-3 levels have also been shown to exhibit a complex relationship with local and systemic effects in patients with ACS (7). Previous experimental studies have reported that IGF-1 increases

Correspondence:

Hüseyin C. HALHALLI

Acil Tıp Bölümü, Sağlık Bilimleri Üniversitesi, Kocaeli Derince Eğitim ve Araştırma Hastanesi, Kocaeli, Türkiye.

e-mail: dr.cahithalhalli@gmail.com 
cardiac contractility and cardiac performance while reducing the wall stress $(8,9)$. GH and IGF-1 receptors can be expressed in myocardial cells. Therefore, GH may have local or systemic effects on the heart, either directly or through induction of IGF-1 (9).

In the present study, the serum levels of GH, IGF-1, and IGFBP-3 were measured in patients diagnosed with AMI in the first $24 \mathrm{~h}$ to evaluate the value of these biomarkers in the pathophysiology and diagnosis of AMI.

\section{MATERIALS AND METHODS}

This prospective study was conducted in patients admitted to the Ankara Training and Research Hospital Emergency Department with chest pain and diagnosed with AMI between January 1 and August 31, 2010.

It included the patients diagnosed with AMI according to the diagnostic criteria published by the European Society of Cardiology and American College of Cardiology (ACC) in 2000. Blood samples for measuring GF, IGF-1, and IGFBP-3 were collected within the first $24 \mathrm{~h}$ from the onset of active chest pain. Also, the clinical characteristics of the patients were recorded.

The control group included healthy men older than 50 years of age, who were admitted to the check-up clinic of the hospital without any symptoms of renal dysfunction, to achieve hormonal homogeneity. The exclusion criteria were as follows: patients who did not agree to participate in the study; patients with kidney failure, liver failure, malignancy, or receiving hormone replacement therapy; and pregnant women. Blood samples for GH, IGF-1, and IGBP-3 assays were collected on the day of admission.

IGFBP-3 levels were measured using DRG Diagnostics Enzymelinked Immunosorbent Assay (ELISA) kits (DRG Instruments GmbH, Germany), IGF-1 levels were measured using DSLR ABS kits with ELISA method, and GH levels were measured using Advia XP Centaur kits with chemiluminescence method.

Statistical evaluation of data was performed using SPSS for Windows 15.0 software package (SPSS, IL, USA). Descriptive data specified in the measure were represented as mean values \pm standard deviation, median, and interquartile range $(I Q R)$. Categorical data were represented as frequencies and percentages. In comparing the AMI and control groups, and in the AMI situations in the two categories, analyses of numerical data with normal distribution were performed using the t test in the independent model. Mann-Whitney U test was used for analyzing data that did not fit a normal distribution, and the chisquare test was used for analyzing categorical data. The cutoff values for GH, IGF-1, and IGFBP-3 variables between the AMI and control groups were determined using receiver operating characteristic (ROC) analysis. A value of $P$ less than 0.05 was considered statistically significant.

\section{RESULTS}

Of This study included 107 patients with AMI and 32 healthy controls. The mean age of the patients and controls was 59.36 $\pm 13: 25$ years and $57.63 \pm 6.55$ years, respectively. In the AMI group, $57.9 \%$ of the patients had comorbid diseases, 38\% had a family history, and $53.3 \%$ had a smoking history. No significant differences were found between the patient and control groups regarding age, body mass index (BMI), history of hypertension, hyperlipidemia, and smoking habits $(P>0.05)$. However, the incidence of diabetes mellitus (DM) was significantly higher in the patient group $(P<0.05)$ (Table 1). In the patient group, 79.4\% of the patients were males, whereas the control group included exclusively men $(P<0.05)$ (Table 1$)$.

In the AMI group, chest pain was present in $85.9 \%$ of the patients. It was found that $42.1 \%$ of these patients were admitted to the $\mathrm{ED}$ in the first $3 \mathrm{~h}$ after the onset of pain. The most common electrocardiographic finding was inferior $\mathrm{MI}$ (35.5\%), and $30.8 \%$ of the patients were diagnosed with non-ST-elevation MI (NSTEMI). The average heart rate and mean arterial pressure of the patients were within normal limits (Table 2).

In the AMI group, the median of GH levels was 1.04 (IQR: 1.86) mg/ $\mathrm{dL}$, the median of IGF levels was 118 (IQR: 91.2), and the median value of IGFBP-3 levels was 3680 (IQR: 2089.0) In the control group, the median of $\mathrm{GH}$ levels was 0.07 (IQR: 0.06$) \mathrm{mg} / \mathrm{dL}$, the median of IGF levels was 141.27 (IQR: 57.37), and the median of IGFBP-3 levels was 2345 (IQR: 359.0). The GH and IGFBP-3 levels were significantly higher in patients diagnosed with AMI $(P<0.05)$, whereas the IGF-1 levels did not significantly differ between the two groups $(P>0.05)$ (Table 3).

According to the ROC analysis of AMI and control groups, the sensitivity of $\mathrm{GH}$ was $84.1 \%$ and the specificity was $81.2 \%$ for the cut-off value of 0.14 ; the sensitivity of IGF-1 was $33.6 \%$, and the specificity was $75 \%$ for the cut-off value of 162 ; and the sensitivity of IGFBP-3 was $75.7 \%$, and the specificity was $96.9 \%$ for the cut-off value of 2862 (Figure 1).

\section{DISCUSSION}

CVDs are the most important cause of morbidity and mortality with increasing frequency all over the world (1). Although electrocardiograms and cardiac markers [troponin, creatine 
TABLE 1: Descriptive values for demographic data of AMI and control groups.

\begin{tabular}{lllll}
\hline & & Control $(\mathrm{n}=32)$ & AMI $(\mathrm{n}=107)$ & $\mathrm{P}$ \\
\hline Age & Mean \pm SD & $57.63 \pm 6.55$ & $59.36 \pm 13.25$ & $>0.05$ \\
Gender & Men, $\mathrm{n}(\%)$ & $32(100 \%)$ & $85(79.4 \%)$ & $<0.01$ \\
BMI & Women, $\mathrm{n}(\%)$ & $0(0 \%)$ & $22(20.6 \%)$ & $>0.05$ \\
Comorbidities & Mean \pm SD & $28.64 \pm 3.78$ & $28.03 \pm 3.72$ & $>0.05$ \\
HT & $\mathrm{n}(\%)$ & $18(44.8 \%)$ & $62(57.9 \%)$ & $>0.05$ \\
DM & $\mathrm{n}(\%)$ & $13(40.6 \%)$ & $42(39.2 \%)$ & $<0.05$ \\
HL & $\mathrm{n}(\%)$ & 0 & $37(34.6 \%)$ & $>0.05$ \\
Family history & $\mathrm{n}(\%)$ & $12(38.7 \%)$ & $98(91.6 \%)$ & $>0.05$ \\
Smoking & $\mathrm{n}(\%)$ & $7(21.9 \%)$ & $38(35.5 \%)$ & $>0.05$ \\
\hline
\end{tabular}

AMI: Acute Myocardial Infarction, BMI: Body Mass Index, DM: Diabetes Mellitus, HL: Hyperlipidemia, HT: Hypertension, SD: Standard Deviation.

kinase (CK)-MB, and myoglobin] have been used in the diagnosis of ACS, they are insufficient in diagnosing patients with unstable angina, and hence new markers are needed.

The peripheral effects of GH generally occur via IGF-1, and 75\% of IGF-1 synthesis occurs in the liver via GH stimulation (10). Varying levels of IGF-1 and its binding protein have been detected in CVD, but no sufficient studies are available on IGFBP-3 levels $(11,12)$.

The proliferation of vascular endothelial cells is very important in the development of macrovascular diseases. Recent studies suggest that IGF-1 may be a true vascular protective factor (13). This effect is provided by resisting endothelial dysfunction due to the stimulation of the production of nitric oxide (NO) in the smooth muscle cells and endothelial cells, by providing vasodilatation via activating $K$ channels (resulting in a decrease in intracellular calcium), and by resisting necrosis in smooth muscle cells and preventing plaque rupture and instability $(13,14)$.

IGF-1 is known to have insulin-like effects and play a role in glucose homeostasis by interacting with the insulin receptor (15). A close relationship between insulin sensitivity and basal N0 production has been reported in healthy people (16). According to a hypothesis, nitric oxide synthase (NOS) activities in the skeletal muscle stimulated by glucose uptake and in the veins stimulated by insulin are mediated by phosphoinositide 3-kinase (PI3K) and protein kinase B (Akt-B). IGF-1 induces the formation of NO, and these metabolic effects are mediated by
TABLE 2: Clinical characteristics of patients with MI

\begin{tabular}{|c|c|c|}
\hline & & $\mathrm{N}(\%)$ \\
\hline \multirow{2}{*}{ Chest pain } & Yes & 15 (14.1) \\
\hline & No & 92 (85.9) \\
\hline \multirow{5}{*}{$\begin{array}{l}\text { Duration } \\
\text { between the } \\
\text { onset of pain } \\
\text { and admission to } \\
\text { the ED }\end{array}$} & No & $15(14)$ \\
\hline & $0-3$ & $45(42.1)$ \\
\hline & $4-6$ & 21 (19.6) \\
\hline & $7-12$ & $14(13.1)$ \\
\hline & $>12$ & $12(11.2)$ \\
\hline \multirow{5}{*}{ AMI } & NSTEMI & $33(30.8)$ \\
\hline & Anterior & $23(21.5)$ \\
\hline & septal & $7(6.5)$ \\
\hline & Inferior & $38(35.5)$ \\
\hline & lateral & $6(5.6)$ \\
\hline \multirow{3}{*}{ Pulse } & $<60$ & $9(8.4)$ \\
\hline & $60-100$ & $84(78.5)$ \\
\hline & $>100$ & 14 (13.1) \\
\hline \multirow{3}{*}{ ABP } & Normal & $70(65.4)$ \\
\hline & Hypotensive & $13(12.1)$ \\
\hline & Hypertensive & $24(22.4)$ \\
\hline
\end{tabular}

ABP: Arterial Blood Pressure, AMI: Acute Myocardial Infarction, ED: Emergency Department, MI: Myocardial Infarction, NSTEMI: Non-ST-Elevation Myocardial Infarction. 
TABLE 3: GH, IGF, and IGFBP-3 levels of patients with AMI

\begin{tabular}{llll}
\hline & $\begin{array}{l}\text { AMI } \\
\text { Median (IQR) }\end{array}$ & $\begin{array}{l}\text { Control } \\
\text { Median (IQR) }\end{array}$ & $P$ \\
\hline GH & $1.04(1.86)$ & $0.07(0.06)$ & $<0.001$ \\
IGF-1 & $118(91.2)$ & $141.27(57.37)$ & 0.391 \\
IGFBP-3 & $3680(2089.0)$ & $2345(359.0)$ & $<0.001$
\end{tabular}

GH: Growth Hormone, IGF-1: Insulin-Like Growth Factors1, IGFBP-3: Insulin-Like Growth Factor-Binding Proteins, IQR: Interquartile Range.

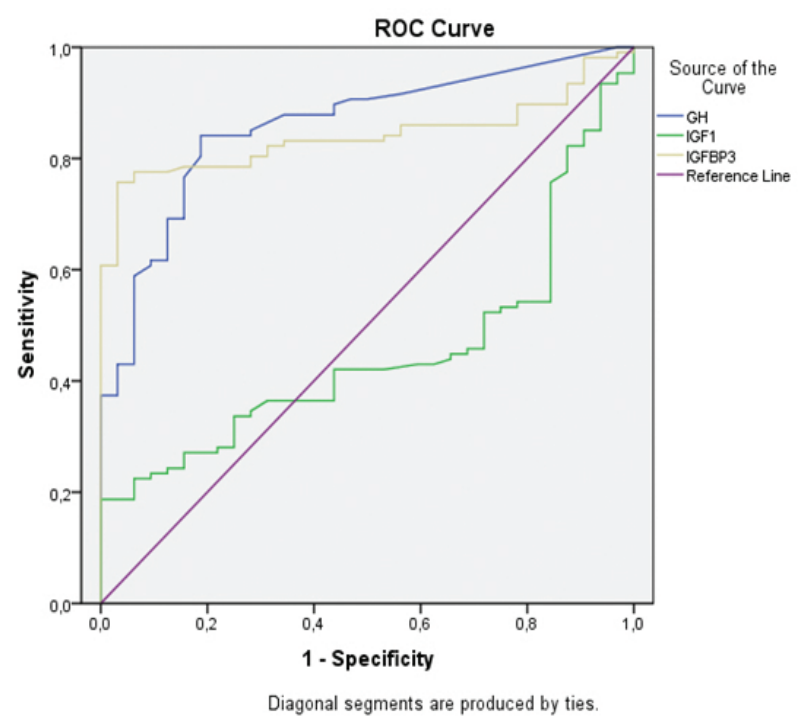

FIGURE 1: ROC analyses of GF, IGF-1, and IGFBP-3.

PI3-K / Akt-B signaling (17). Despite insufficient data on the effects of IGF-1 in the vascular endothelial function in insulin resistance, it has been suggested that changes in the sensitivity of vascular IGF-1 play a role in the development of endothelial dysfunction in cases of insulin resistance (18).

In patients with uncontrolled DM, it has been reported that usually IGF-1 levels decrease, IGFBP-1 levels increase, and $\mathrm{GH}$ levels occasionally increase (19). The disturbance in this balance between insulin and glucose clinically reflects as an increase in microvascular complications (19). Also, it has been reported that IGF-1 has a vasculoprotective effect and hence IGF-1 levels decrease in organized atherosclerotic plaques $(20,21)$. It has been found that IGF-1 levels decrease with higher blood lipid levels $(22,23)$. Kawachi et al and Wataneble et al have found a relationship between subclinical carotid artery disease and high levels of IGFBP-3in middleaged men $(24,25)$. Juul et al, in their Dan-MONICA study, have found that low IGFBP-3 levels reduce the incidence of ischemic heart disease (26). It is suggested that IGF-1 levels decrease and IGFBP-3 levels increase over time due to an increase in degradation products and comorbid diseases, and $\mathrm{GH}$ increases secondarily.

Copeland at al found that infusion of IGF-1 into the brachial artery caused an increase in blood flow in the forearm (27). Tsukahara et al reported that IGF-1 stimulates the relaxation of precontracted isolated arteries depending on the concentration (28). In both the cases, this effect was eliminated by NOS inhibitor NG-monomethyl-L-arginine $(27,28)$. It has been shown in mice that inactivation of IGF-1 increases endothelin-1 mRNA levels in the aorta and impairs vasorelaxation induced by acetylcholine in mesenteric vascular resistance (29).

Kaplan et al found that IGF-1 and IGFBP-1 levels were associated with AMI (30). Conti et al, in a study conducted in 23 patients with AMI, found that IGF-1 levels significantly decreased in the early phase of MI compared with healthy controls (31). Spallaross et al found that IGF-1 levels were significantly lower in patients who underwent coronary angiography and were diagnosed with severe coronary artery stenosis than in those with no such diagnosis (32). It is believed that this increase in IGF-1 levels is not associated with AMI; rather a sudden decrease in IGF-1 levels triggers AMI.

IGF-1 concentration has been shown to be higher in coronary vascular smooth muscle cells in patients with CVD (14). However, recent experimental and clinical research suggests the opposite; it suggests a low-level relationship between IGF-1 concentration and CVD $(33,34)$. It has been shown that the levels of IGFbinding proteins decrease due to neurohormonal changes after experimentally induced AMI, and this reduction has been known to have a direct correlation with IGF-1 levels $(35,36)$.

Goodman-Gruen et al reported that GH levels increase acutely in patients with AMI (37). Sekuri et al, in their study conducted in 30 patients with ACS, found that IGF-1 levels significantly decreased in patients with acute STEMl; however, they did not find any decrease in serum IGFBP-3 levels (38). Yamaguchi et al found that serum IGF-1 levels were significantly lower in patients with AMI (39). The present study found that GH and IGFBP-3 levels were higher, and IGF-1 levels were lower, though not significantly, in 
the patient group compared with the control group. It is suggested that GH and IGF-1 levels increase due to increasing stress in cases of ACS. On the contrary, it is believed that IGFBP-3 levels are already high before MI depending on IGF-1 levels.

Yamaguchi et al, in their study on AMI, found IGF-1 to be an independent predictor of 90-day mortality (39). Juul et al reported that lower IGF-1 levels and higher IGFBP-3 levels are effective in mortality and morbidity in coronary heart disease (26). Conti et al reported that each reduction of $40 \mathrm{ng} / \mathrm{L}$ in basal IGF-1 levels led to a relatively $38 \%$ increase in the risk of mortality (31). In the light of this study, it is believed that the decrease in IGF-1 levels and the increase in IGFBP-3 levels are not consequences of $\mathrm{Ml}$; rather this change leads to $\mathrm{MI}$.

The cardiac markers (troponin and (K-MB) used in the diagnosis of AMI have very high sensitivity and specificity $(1,3)$. Although the high sensitivity and specificity of GH and IGFBP-3 levels suggest that these can be used as biomarkers, large-scale studies are needed to validate the conclusion. Also, these markers should be included in the parameters used to calculate the probability of $\mathrm{MI}$ in patients with a high risk of MI.

\section{REFERENCES}

1. Lozano R, Naghavi M, Foreman $\mathrm{K}$, et al. Global and regional mortality from 235 causes of death for 20 age groups in 1990 and 2010: a systematic analysis for the Global Burden of Disease Study 2010. Lancet 2012;380:2095-2128.

2. Onat A, Hergenç G, Sansoy V, ark. TEKHARF, Türk Halkının Kalp Sağlığı. İstanbul, 2007.

3. Green GB, Hill PM. Cardiovascular disease Approach to chest pain and possible myocardialischemia. In: Emergency Medicine: A Comprehensive Study Guide. Ed by Tintinalli JE, Kelen GD, Stapczynski JS, 5th ed. Notrh Carolina: McGrawHill. pp 341-51, 1999.

4. Le Roith D, Scavo L, Butler A. What is the role of circulating IGF-I Trends. Endocrinol Metab 2001; 12(2):48-52.

5. Nyomba BL, Berard L, Murphy LJ. Free insulin-like growth factor I (IGF-I) in healthy subjects: relationship with IGFbinding proteins and insülin sensitivity. J Clin Endocrinol Metab 1997; 82(7):2177-81.

6. Hwa V, Oh Y, Rosenfeld RG. The insulin-like growth factorbinding protein (IGFBP) super family. Endocr Rev 1999; 20(6):761-87.

7. Gibbons RJ, Antman EM. ACC/AHA 2002 Guideline update for the management of patients with unstable angina and non-ST segment elevation myocardialin farction- Summary article. A report of the American College of Cardiology/ American Heart Association task Force on Practice Guidelines. J Am Coll Cardiol 2002; 40:1366-74.
8. Moller DE, Flier JS. Insulin resistance-mechanisms, syndromes, and implications. N Engl J Med 1991; 325(13):938-48.

9. Volterrani M, Giustina A, Manelli F, Cicoira MA, Lorusso R, Giordano A. Role of growth hormone in chronic heart failure: therapeutic implications. Ital Heart J 2000; 1(11):732-8.

10. Roith DL. The Insulin-Like Growth Factor System. Experimental Diabetes Research 2003; 4(4): 205-12.

11. Colao A, Spiezia S, Di Somma C, Pivonello R, Marzullo P, Rota F, MusellaT, Auriemma RS, De Martino MC, Lombardi G. Circulating insulin-like growth factor-I levels are correlated with the atherosclerotic profile in healthy subjects in dependently of age. J Endocrinol Invest 2005; 28(5):440-8.

12. Van den Beld AW, Bots $M L$, Janssen JA, Pols HA, Lamberts SW, Grobbee DE. Endogenous hormone sand carotida the rosclerosis in elderly men. Am J Epidemiol 2003; 157(1):25-31.

13. Conti E, Pitocco D, Capoluongo E, Zuppi C, Ghirlanda G, Crea F, Andreotti F. IGF-1 and macrovascular complications of diabetes: alternative interpretations of recently published data. Diabetes Care 2003; 26(5):1653-4.

14. Grant MB, Wargovich TJ, Ellis EA, Caballero S, Mansour M, Pepine CJ. Localization of insulin-like growth factor I and inhibition of coronary smooth muscle cell growth by somatostatin analogues in human coronary smooth muscle cells. A potential treatment for restenosis? Circulation 1994; 89(4):1511-7.

15. Harbili S. İnsülin benzeri büyüme faktörleri (IGF): Egzersiz metabolizması ve kas dokusu üzerine etkileri. Genel Tıp Derg 2008; 18(4):177-84.

16. Petrie JR, Ueda S, Webb DJ, Elliott HL, Connell JM. Endothelial nitric oxide production and insülin sensitivity. A physiological link with implications for pathogenesis of cardiovascular disease. Circulation 1996; 93(7):1331-3.

17. Sowers JR. Insulin resistance and hypertension. Am J Physiol Heart Circ Physiol 2004; 286(5):H1597-602.

18. Ezzat VA, Duncan ER, Wheatcroft SB, Kearney MT. The role of IGF-I and its binding proteins in the development of type 2 diabetes and cardiovascular disease. Diabetes Obes Metab 2008; 10(3):198-211.

19. Ranke MB. Insulin-like growth factor-I treatment of growth disorders, diabetes mellitus and insülin resistance. Trends Endocrinol Metab 2005; 16(4):190-7.

20. Okura Y, Brink M, Zahid AA, Anwar A, Delafontaine P. Decreased expression of insulin-like growth factor-1 and apoptosis of vascular smooth muscle cells in human atherosclerotic plaque. J Mol Cell Cardiol 2001; 33(10):1777-89.

21. Patel VA, Zhang QJ, Siddle K, Soos MA, Weissberg PL, Bennett MR. Defect in insulin-like growth factor-1 survival mechanism in atherosclerotic plaque-derived vascular smooth muscle cells is mediated by reduced surface binding and signaling. Circ Res 2001; 88: 895-902.

22. Malik J, Stulc T, Ceska R. Unraveling Reaven's syndrome $X$ : serum insulin-like growth factor-I and cardiovascular disease. Circulation 2003; 107(20):e190-2.

23. Ruotolo $G$, Båvenholm P, Brismar K, Eféndic S, Ericsson CG, de Faire U, Nilsson J, Hamsten A. Serum insulin-like growth factor-I level is independently associated with coronary artery disease progression in young male survivors of myocardial infarction: beneficial effects of bezafibra tetreatment. J Am Coll Cardiol 2000; 35(3):647-54. 
24. Kawachi S, Takeda N, Sasaki A, Kokubo Y, Takami K, Sarui H, Hayashi M, Yamakita N, Yasuda K. Circulating insulinlike growth factor-1 and insulin-like growth factor binding protein-3 are associated with early carotida therosclerosis. Arterioscler Thromb Vasc Biol 2005; 25(3):617-21.

25. Watanabe $T$, Itokawa $M$, Nakagawa $Y$, Iguchi $T$, Katagiri $T$. Increased levels of insulin-like growth factor binding protein-3 in hypertensive patients with carotida therosclerosis. Am J Hypertens 2003; 16(9 Pt 1):754-60.

26. Juul A, Scheike T, Davidsen M, Gyllenborg J, Jørgensen T. Low serum insulin-like growth factor I is associated with increased risk of ischemich heart disease: a populationbased case-control study. Circulation 2002; 106(8):939-44.

27. Copeland KC, Nair KS. Recombinant human insulin-like growth factor-I increases fore arm blood flow. J Clin Endocrinol Metab 1994; 79(1):230-2.

28. Tsukahara H, Gordienko DV, Tonshoff B, Gelato MC, Goligorsky MS. Direct demonstration of insulin-like growth factor-I-induced nitric oxide production by endothelial cells. Kidney Int 1994; 45(2):598-604

29. Tivesten A, Bollano E, Andersson I, Fitzgerald S, Caidahl K, Sjögren K, Skøtt O, Liu JL, Mobini R, Isaksson OG, Jansson JO, Ohlsson C, Bergström G, Isgaard J. Liver-derived insulinlike growth factor-I is involved in the regulation of blood pressure in mice. Endocrinology 2002; 143(11):4235-42.

30. Kaplan RC, McGinn AP, Pollak MN, Kuller LH, Strickler HD, Rohan TE, Cappola AR, Xue X, Psaty BM. Association of total insulin-like growth factor-I, insulin-like growth factor binding protein-1 (IGFBP-1), and IGFBP-3 levels with incident coronary events and ischemic stroke. J Clin Endocrinol Metab 2007; 92(4):1319-25.

31. Conti E, Andreotti F, Sciahbasi A, Riccardi P, Marra G, Menini E, Ghirlanda G, Maseri A. Markedly reduced insulin-like growth factor-1 in the acute phase of myocardial infarction. J Am Coll Cardiol 2001; 38(1):26-32.
32. Spallarossa $P$, Brunelli $C$, Minuto $F$, Caruso D, Battistini $M$, Caponnetto S, Cordera R. Insulin-like growth factor-I and angiographically documented coronary artery disease. Am J Cardiol 1996; 77(2):200-2.

33. Sandhu MS, Heald AH, Gibson JM, Cruickshank JK, Dunger DB, Wareham NJ. Circulating concentrations of insulin-like growth factor-I and development of glucose intolerance: a prospective observational study. Lancet 2002; 359(9319):1740-5.

34. Unden AL, Elofsson S, Knox S, Lewitt MS, Brismar K. IGF-I in a normal population: relation topsychosocial factors. Clin Endocrinol (Oxf) 2002; 57(6):793-803.

35. Rajkumar K, Krsek M, Dheen ST, Murphy LJ. Impaired glucose homeostasis in insulin-like growth factor binding protein-1 transgenic mice. J Clin Invest 1996; 98(8):1818-25.

36. Murphy LJ, Rajkumar K, Molnar P. Phenotypic manifestations of insulin-like growth factor binding protein-1 (IGFBP-1) and IGFBP-3 over expression in transgenic mice. Prog Growth Factor Res 1995; 6(2-4):425-32.

37. Goodman-Gruen D, Barrett- Connor E, Rosen C. IGF-I and ischemic heart disease in older people. J Am Geriatr Soc 2000; 48(7): 860-1.

38. Sekuri C, Arslan O, Utük O, Bayturan O, Onur E, Tezcan UK, Tavli T. [Serum level of insulin-likegrowth factor-1 and insulin-like growth factor binding protein-3 in acute coronary syndrome sand relationship with prognosis]. Anadolu Kardiyol Derg 2004; 4(3):209-12.

39. Yamaguchi $\mathrm{H}$, Komamura K, Choraku M, Hirono A, Takamori $\mathrm{N}$, Tamura $\mathrm{K}$, Akaike M, Azuma H. Impact of serum insulinlike growth factor-1 on early prognosis in acute myocardial infarction. Intern Med 2008; 47(9):819-25. 